\title{
Climatological coupling of the thermohaline decadal changes in Central Water of the Eastern North Atlantic*
}

\author{
F.F. PÉREZ1 ${ }^{1}$, R.T. POLLARD ${ }^{2}$, J.F. READ ${ }^{2}$, V. VALENCIA ${ }^{3}$, J.M. CABANAS ${ }^{4}$ \\ and A.F. RÍOS ${ }^{1}$ \\ ${ }^{1}$ Instituto Investigacións Mariñas (CSIC), c/Eduardo Cabello, 6. 36208 Vigo. Spain. E-mail: fiz@iim.csic.es \\ ${ }^{2}$ Southampton Oceanography Centre, Empress Dock Southampton, SO14 3ZH, UK. \\ ${ }^{3}$ AZTI Instituto Tecnológico Pesquero y Alimentario, Avda. Satrústegui, 8, 20008 San Sebastian, Spain. \\ ${ }^{4}$ Instituto Español de Oceanografía. Centro Oceanográfico de Vigo. Apartado 1552, 36280 Vigo, Spain.
}

\begin{abstract}
SUMMARY: Data collected at $42^{\circ} \mathrm{N}, 10^{\circ} \mathrm{W}$ in the intergyre region of the Northeast Atlantic show significant year to year variability in the T-S characteristics of the upper $800 \mathrm{~m}$ of the water column. Taking salinity values on the $\sigma_{\theta}=27.1 \mathrm{~kg} \mathrm{~m}^{-3}$ isopycnal as representative of the Eastern North Atlantic Central Water mass it was found that the variability correlates well with the wind stress at $43^{\circ} \mathrm{N}, 11^{\circ} \mathrm{W}$, with cumulative river discharge (which we take as an index of precipitation over the ocean) and with the NAO (which is an index of the strength and position of storm tracks and the state of the evaporationprecipitation balance). The covariation illustrates the close coupling between water mass formation and climate in the North Atlantic, where climate changes affect the deep ventilation by which ENACW is formed and the evaporation-precipitation balance from which the T-S signature results. Hints of a 20 year cycle in the ocean correlate with a 20 year periodicity in the NAO. It remains to be established whether there is a feedback mechanism by which water mass anomalies affect the climate and the intensity and variation of the NAO pattern, and the extent to which upper ocean observations can be used as an indicator of future climate trends.
\end{abstract}

Key words: decadal changes, T-S, North Atlantic, NAO, ENACW.

\section{INTRODUCTION}

Interannual changes in the temperature-salinity (T-S) relationship of Eastern North Atlantic Central Water (ENACW) are very useful to evaluate the long-term exchange of water and heat within the main thermocline, down to 500-800 meters depth (Jenkins, 1982). This process reaches its maximum in late winter as the sum of several long-term processes: horizontal advection, vertical mixing, precipitation and evaporation, loss of heat to the air. The history of the surface layer is important because

\footnotetext{
*Received July 5, 1999. Accepted May 29, 2000.
}

the accumulation of salt and heat in the mixed layer is variable, consequently, climatological variations can produce an important imprint in the thermohaline properties of ENACW which remains at least one year after the water mass formation.

Mean circulation in the area limited by the subpolar gyre, the subtropical gyre (between the North Atlantic and Azores Currents) and the European shelf is very weak (Maillard, 1986) (Fig. 1) allowing the formation of pycnostads of new mode waters (Harvey, 1982). The upper $500 \mathrm{~m}$ are primarily occupied by ENACW (Pollard et al., 1996), a body of water well-defined by T-S characteristics, formed each year by air-sea interaction across a wide band 


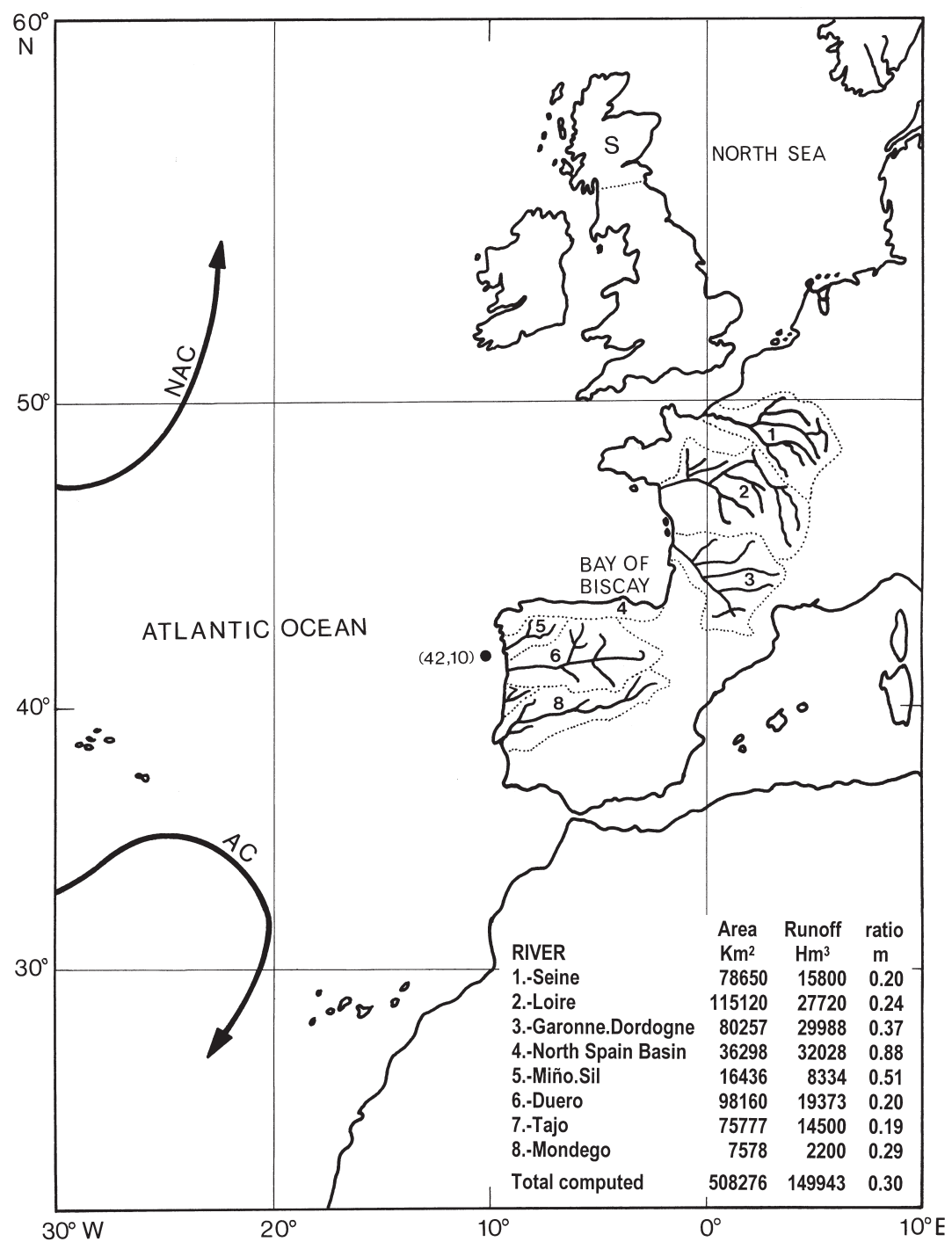

FIG. 1. - The Eastern North Atlantic intergyre zone bounded by the North Atlantic Current (NAC) and the Azores Current (AC), according to Sy (1988). River drainage basins are identified by numbers and their areas and discharges shown in a table inset. S represents the Scottish rivers drainage basin. The black point indicates the position $\left(42^{\circ} \mathrm{N}, 10^{\circ} \mathrm{W}\right)$ where the historical data used for Fig. 3 , were obtained.

of latitudes (Iselin, 1939). From $20^{\circ} \mathrm{W}$, salinity on the $27.1 \mathrm{~kg} \mathrm{~m}^{-3}$ isopycnal surface increases progressively to the east rather than decreasing from the effects of coastal runoff (Pollard and Pu, 1985; Pérez et al., 1995). The spatial trend is similar in different years despite interannual variability in the T$\mathrm{S}$ characteristics. Pérez et al. (1995), from the database of several oceanographic cruises in the North Atlantic, showed a temporal variation in the T-S relationship and the evolution of salinity on the isopycnal $\sigma_{\theta}=27.1 \mathrm{~kg} \mathrm{~m}^{-3}$ at $42^{\circ} \mathrm{N}, 10^{\circ} \mathrm{W}(42,10)$. This paper uses the same database updated to include more recent data. According to Pérez et al. (1995), this site $(42,10)$ is sufficiently far from the coast to escape the influence of continental runoff at densities greater than $\sigma_{\theta}=27.0 \mathrm{~kg} \mathrm{~m}^{-3}$. Also, small deviations from the reference position $(42,10)$ are not significant because the central water T-S relationship is rather constant over a wide area. Therefore, our findings are not aliased by variations in the position nor by variations in the months in which the measurements were made.

This paper explores the interannual variation of salinity on the isopycnal $27.1 \mathrm{~kg} \mathrm{~m}^{-3}$ and its relationship with the North Atlantic Oscillation (NAO) and the large scale freshwater flux in terms of evaporation minus precipitation (E-P). The NAO is one of a number of "teleconnection patterns" found in the atmosphere that represent recurring large-scale pressure patterns and circulation anomalies. The 
NAO is the primary teleconnection pattern of the northern hemisphere extratropical circulation in the Atlantic sector. It is defined as the normalised pressure difference between the Azores and Iceland. A high or positive NAO index is characterised by a strong Iceland low with a strong Azores ridge of high pressure to the south, storm tracks are shifted to the north generating high rainfall levels over Northwest Europe and Scandinavia and lower than average rainfall (drought) over Southern Europe, the intergyre region $\left(40-50^{\circ} \mathrm{N}\right)$ tends to salinify while the subpolar gyre $\left(50-60^{\circ} \mathrm{N}\right)$ freshens. Conversely a low or negative NAO index has the opposite phase, unusually high pressure over Iceland and Greenland and low pressure along the Azores ridge. This shifts the storm track southwards bringing higher rainfall to Southern Europe and drier conditions to the northwest, the upper ocean in the inter-gyre region tends to freshen and the subpolar gyre salinifies.

In this paper we use the NAO index published by the Climate Prediction Centre of the National Centre for Environment Prediction (NCEP), a part of the National Oceanic and Atmospheric Administration (NOAA). It is calculated by rotated principal component analysis of the entire flow field and the monthly analyses are based on three month periods. This reduces extrema and provides a more robust result than grid-point-based analyses where the NAO is typically determined from anomalies at a few select locations (Hurrell, 1995; Jones et al.,1997).

\section{RESULTS AND DISCUSSION}

The evolution of the T-S relationship around $(42,10)$ from 1990 to 1995 (Fig. 2a) shows that in April 1990, the T-S profiles were very close to the ENACW reference line (Ríos et al., 1992). Average salinity on the $27.1 \mathrm{~kg} \mathrm{~m}^{-3}$ isopycnal surface was $35.622 \pm 0.012$ at $253 \pm 78 \mathrm{~m}$ along $42^{\circ} \mathrm{N}$. The $27.1 \mathrm{~kg}$ $\mathrm{m}^{-3}$ isopycnal outcropped at $44^{\circ} \mathrm{N}$ during the preceding year. During 1991 a strong thermohaline change shifted the T-S relationship to higher salinity and/or lower temperatures. Salinity on the $27.1 \mathrm{~kg} \mathrm{~m}^{-3}$ isopycnal was greater than 35.80 , and its outcropping region moved southward to $42^{\circ} \mathrm{N}$ (Pérez et al., 1995). This agrees with the strong winter mixing and cooling inferred in late winter 1991 by Pollard $e t$ al. (1996) which resulted in i) greater depth of winter mixing, ii) southward displacement of the isopycnal outcrop and iii) increase of the salinity on each isopycnal surface (Jenkins, 1982). The salinity increase was even higher at depths shallower than the $27.1 \mathrm{~kg} \mathrm{~m}^{-3}$ isopycnal, forcing the slope of the T$\mathrm{S}$ curve close to the critical value that allows the downward penetration of salt by double diffusion (Schmitt, 1981). Subsequent freshening (or warming) brought the T-S profiles back towards the reference curve, but left a north-south gradient in 1995, when profiles to the north were split into two segments. Strong freshening of ENACW above the 27.1 $\mathrm{kg} \mathrm{m}^{-3}$ isopycnal created a stable upper layer above
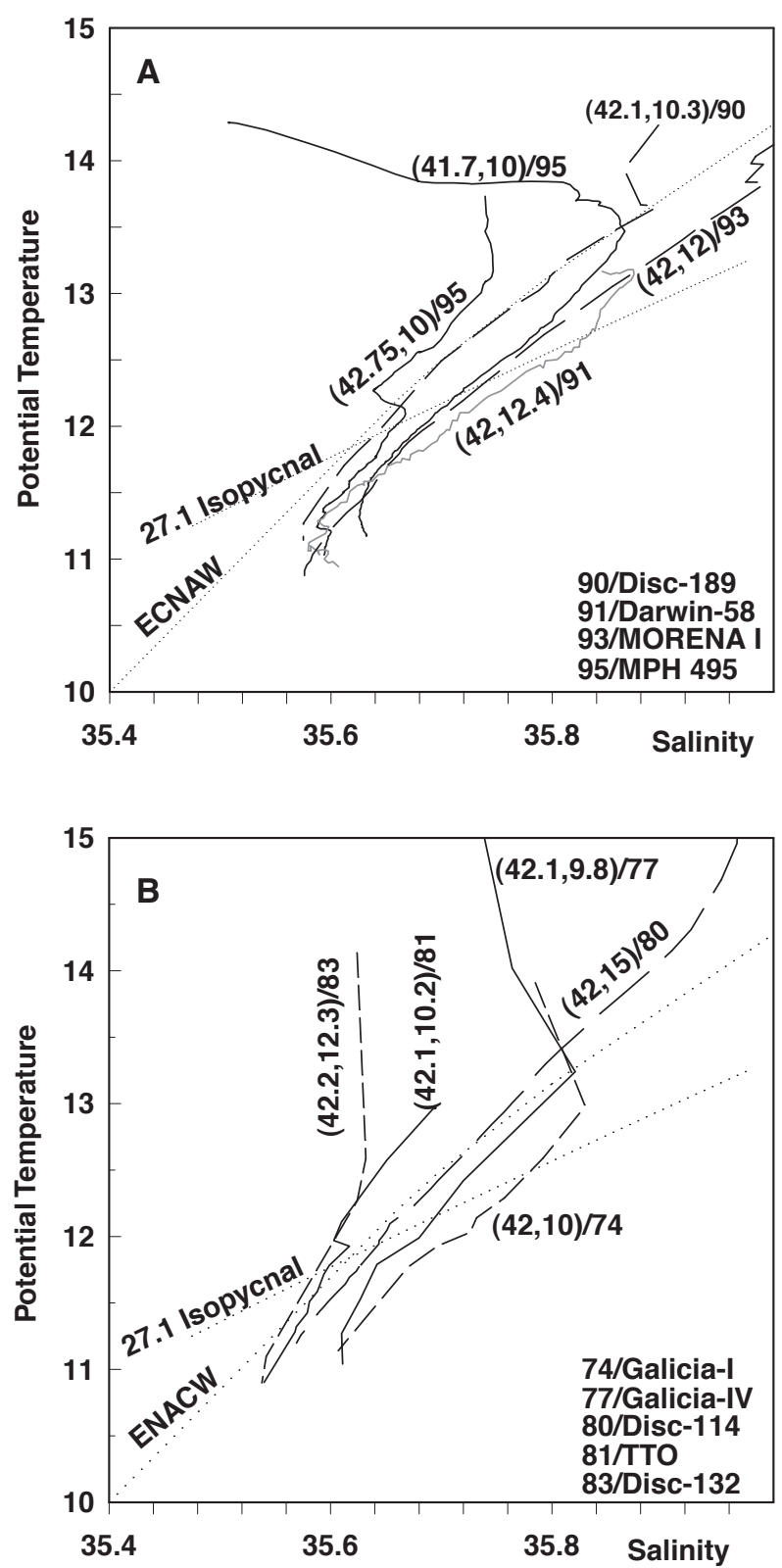

FIG. 2. - T-S relationship (a) from 1990 to 1995 and (b) from 1974 to 1983 . Each profile is labeled with latitude and longitude in brackets and the year. Cruises are shown in the legend. The 27.1 isopycnal is shown with the ENACW reference line (Ríos et al. 1992). 
a pycnocline which prevented the downward propagation of this freshening.

A high salinity event in the ENACW was also observed in the early 1970's (Fig 2b). T-S profiles at $(42,10)$ in 1974 (and 1977) showed a strong salinization of ENACW. Subsequent profiles showed freshening similar to that observed in the 1990's, with the greatest freshening at densities above the $27.1 \mathrm{~kg} \mathrm{~m}^{-3}$ isopycnal.

Within its long-term variability, the NAO exhibits spectral peaks at periods of 20 and 7.3-8.0 years (Rogers, 1984) or 24, 8 and 2.1 years (Cook et al., 1998). Variations in the spreading of newly formed intermediate mode water from the Labrador Sea (LSW) around the subpolar gyre has been described at about 18 years (Read and Gould, 1992) or 7-8 years (Sy et al., 1997). Advection of surface salinity anomalies have also been described (Dickson et al., 1988) with a cycle of 21 years. These results begin to hint at a number of levels of periodicity within the North Atlantic subpolar gyre circulation.

Salinity on the $27.1 \mathrm{~kg} \mathrm{~m}^{-3}$ isopycnal at $(42,10)$ plotted against time (Fig. 3 ) shows a cycle of maximum salinity, and probably minimum temperature in the intergyre region in the early 70's and 90's (Fig. 3) with minimum salinity in the 1980's, an inverse correlation with the LSW cycle. Thus increased salinity of the intergyre zone tends to be accompanied by decreased salinity of the subpolar gyre to the north and vice versa. hinting at a large scale coordinated oceanic response to external forcing (Dickson et al.,1996).

Northerly wind-stress estimated by geostrophic winds (Bakun, 1973; Lavín et al., 1990) at $43^{\circ} \mathrm{N}$, $11^{\circ} \mathrm{W}$ averaged over the period July-December during the year previous to each cruise (Fig. 3) correlates with the salinity time series $\left(r^{2}=0.66\right)$. The usually wet southerly winds in autumn are associated with freshening of ENACW while dry northerly winds in autumn correlated with the salinification of ENACW.

The wind regime is a direct result of the atmospheric pressure gradient and NAO provides a measure of this. One of the characteristics of the NAO is a marked negative correlation between the polar low and subtropical high in the North Atlantic (Rogers and Loon, 1979). The average situation in January (Fig. 4a) with low pressure centered over Greenland and a high pressure ridge between $20^{\circ}-40^{\circ} \mathrm{N}$ consti-

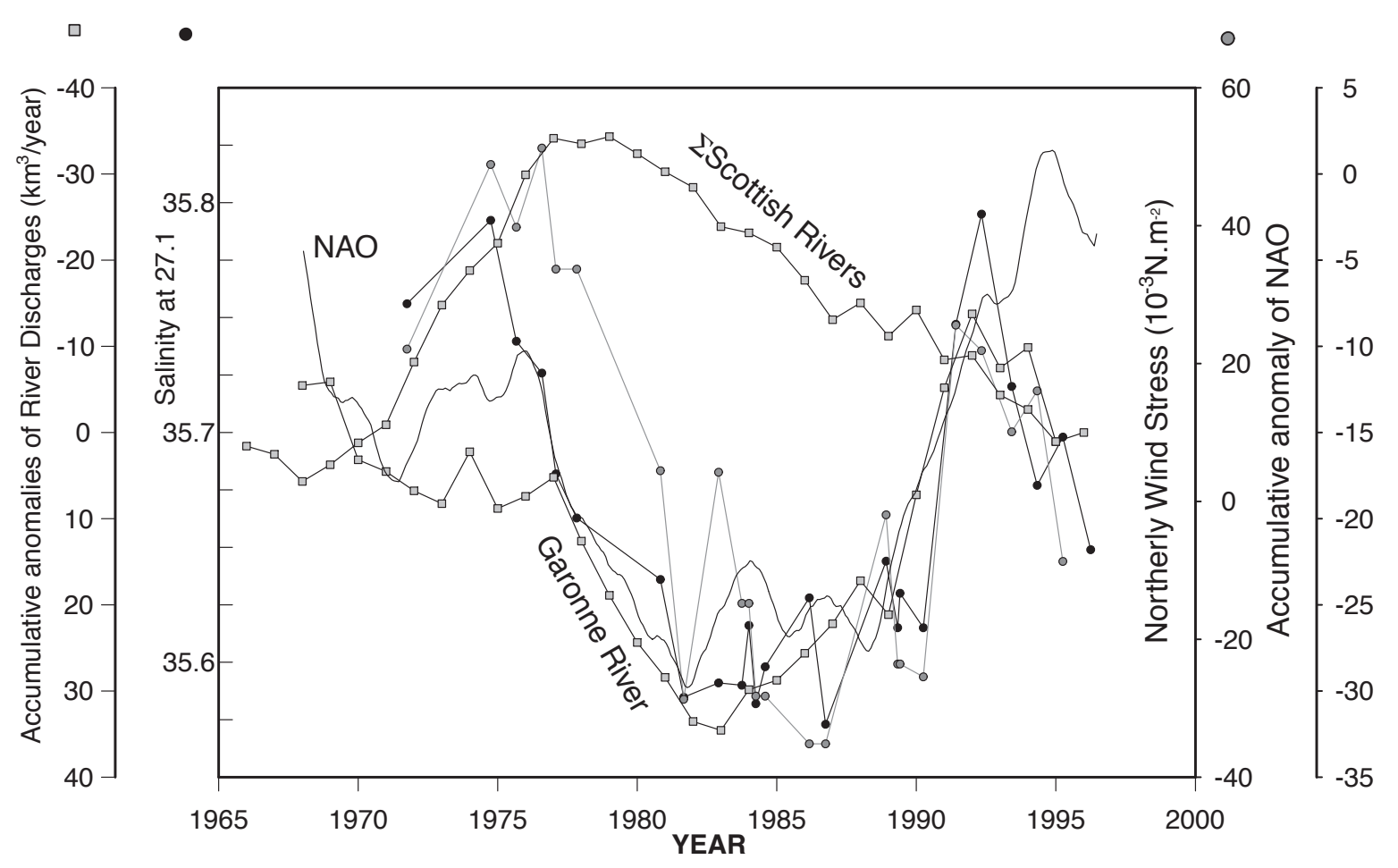

FIG. 3. - Interannual variability of salinity on the isopycnal level of 27.1 (about $150-300$ meters) at stations around $42^{\circ} \mathrm{N}, 10^{\circ} \mathrm{W}$ (dark circles), and the average northerly wind stress during the period July-December in the former year (open circles). The accumulative annual anomalies of discharges from the Garonne River and Scottish rivers during the former year are also shown (dark squares). The annual discharge of Garonne River and Scottish rivers was $30 \mathrm{~km}^{3}$ and $29 \mathrm{~km}^{3}$, respectively. The continuous line represents the accumulative anomaly of NAO index. 
tutes a typical positive anomaly. Vectors of the vertically integrated moisture transports (Fig. $4 \mathrm{~b}$ from J.W. Hurrell, 1995) show strong westerlies across the North Atlantic with drier conditions over much of central and southern Europe and wetter conditions from Iceland through Scandinavia (Rogers and Loon, 1979; Hurrell, 1995). Conversely low (or negative anomaly) NAO index winters (Fig. 4c) have the opposite conditions, i.e. weak westerlies, increased precipitation over southern Europe and drier weather over Iceland and Scandinavia. Oceanic heat and water flux anomalies are linked to local wind directions with the largest positive anomalies associated with northerly to northwesterly winds (Cayan, 1992a,b).

Regional river discharge is used as a gauge of precipitation (initially over southern Europe) to determine the variability of water input from the atmosphere into the intergyre region (Fig 1), as it is assumed that the interannual variability in precipitation is reflected in the discharge. For example, coastal precipitation measurements present a good correlation with discharge from the Miño, Garonne and Dordogne rivers. Salinity in the upper ocean is effectively an integral of the annual evaporationprecipitation balance, therefore river discharge must be integrated to make it comparable to changes in salinity. The integrated mean residual discharge of Garonne and Dordogne rivers provides an index of the interanual excess or deficit of fresh water in the upper layer (Fig. 3). In general, the annual cycles of estimated ocean and land precipitation are very similar (Cayan and Reverdin, 1994). Therefore we assume a direct relation between river discharge and precipitation over the ocean. Although river discharge is a source of freshening within the main thermocline, the main fresh water flux comes from direct exchange with the atmosphere.

Salinity changes in the surface layer occurred before changes in ENACW, eg. during 1989 and 1990 increased salinity was observed (Cayan, 1992b, Cayan and Reverdin, 1994) in surface water along the northeastern boundary of the North Atlantic but corresponding changes in ENACW were not observed until 1991. The accumulative annual river discharge anomaly shows a negative correlation with the salinity on the $27.1 \mathrm{~kg} \mathrm{~m}^{-3}$ isopycnal surface $\left(r^{2}=0.74\right)$ (Fig. 3). Between 19761981 the increase in annual discharge resulted in an anomaly equivalent to the water flow in one year. The equivalent fresh water flux reflects an annual precipitation of about $80 \mathrm{~cm}$ (Rogers and Loon,
1979; Cayan and Reverdin, 1994) and implies a decrease in salinity of 0.095 over a layer $300 \mathrm{~m}$ deep. From 1982 to 1987 the annual discharge was close to the average of the whole period ( 25 year) and the accumulative fresh water flow anomaly did not change appreciably. From 1988 to 1991 discharge decreased progressively, and the salinity in the ENACW changed dramatically in 1991.

The total discharge of all the rivers draining into the intergyre region provides a fresh water flux of about $150 \mathrm{~km}^{3}$ (Fig. 1). If this is distributed evently between 40 to $50^{\circ} \mathrm{N}$ and $21^{\circ} \mathrm{W}$ to the European coast, the volume is equivalent to an annual precipitation of $15 \mathrm{~cm}$. This represents a low percentage $(18 \%)$ of the probable excess or deficit of precipitation minus evaporation in the open sea. It brings the total salinity increase to 0.113 , which is still lower than the observed range of 0.23 in the salinity on $27.1 \mathrm{~kg} \mathrm{~m}^{-3}$ isopycnal. The observed change is higher than the calculated change because the increased cooling during formation of ENACW raises the isopycnal surfaces causing an apparent increase in salinity (Jenkins, 1982), so the real change is a combination of cooling and deficit of freshwater (Pollard et al., 1996). In the extratropics cool air (northerly winds) is usually drier (Cayan, 1992a) reinforcing the sensible and latent heat flux and heat anomalies which often exceed $100 \mathrm{Wm}^{-2}$ over several hundred square kilometres (Cayan, 1992a). During the period 1976 to 1981 the excess of precipitation and warming covaries with westerly and southerly winds. The contributions of heat and salt to the density flux, computed separately for the North Atlantic (Schmitt et al., 1989), show that the thermal density flux dominates at high and low latitudes whereas the haline density flux is more important in the subtropics, particularly on the eastern side of the basin. The monthly precipitation and evaporation variability estimated over the North Atlantic (Cayan et al., 1994) show also that the precipitation is the most important source of variability of fresh water flux in the intergyre zone.

To test the premise that the NW European region will be subject to the opposite conditions to those in SW Europe the river discharge data from Scotland was compared with that of the Garonne. The accumulated anomaly of Scottish rivers discharge show a significant inverse correlation with the Garonne as expected. The offset between them arises because they are not equidistant from the maximum pressure gradient of the NAO. The Garonne and Miño basins are relatively close to the ridge of high pressure 

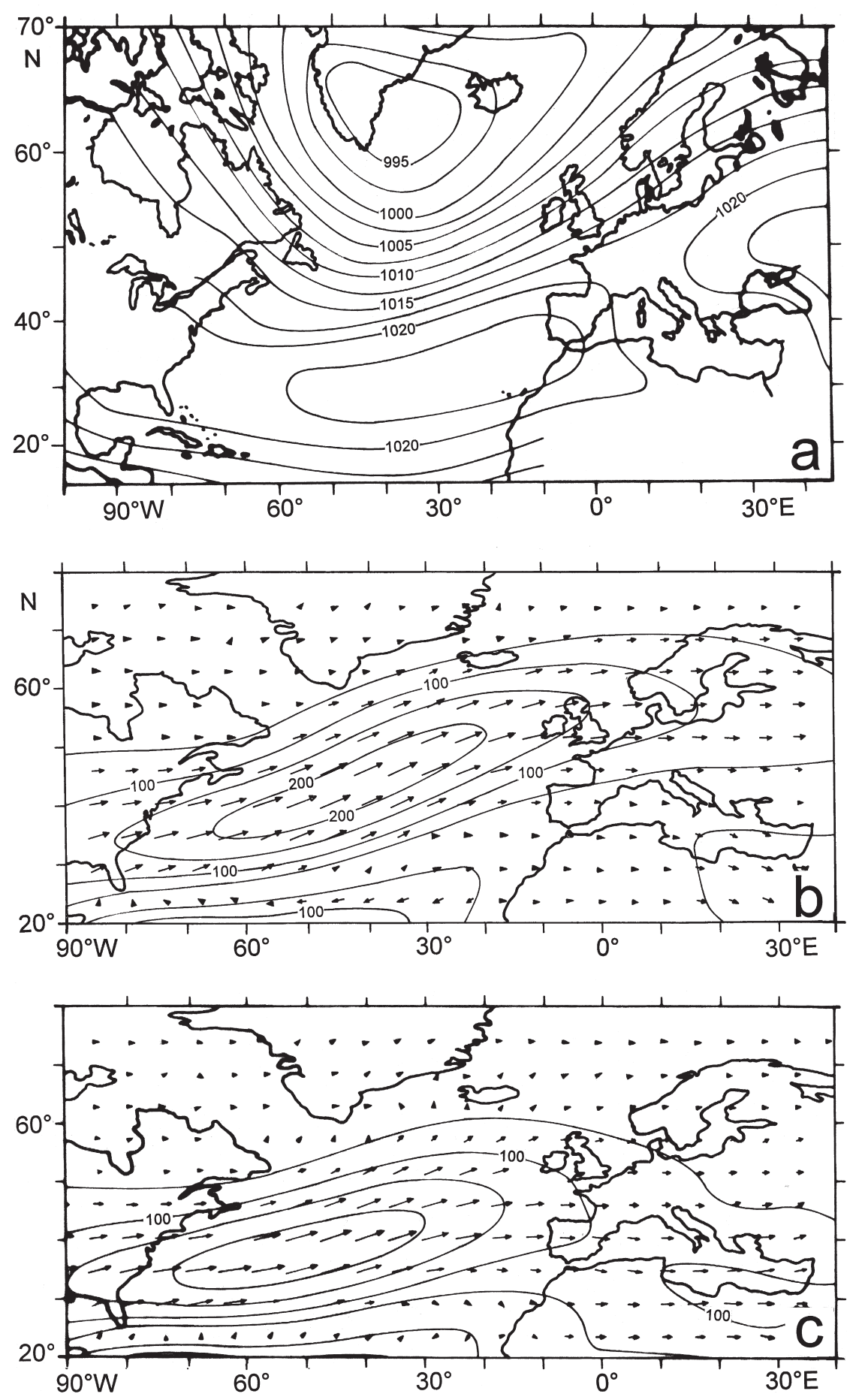

FIG. 4. - An average sea level pressure (mb) in January where the low is centered in Greenland and the high along $30^{\circ} \mathrm{N}$ (a). Vectors of the vertically integrated moisture transport $\left(\mathrm{kg} \mathrm{m}^{-1} \mathrm{~s}^{-1}\right)$ for (b) high NAO index winters and (c) normal or low NAO index winters, according to Hurrell (1995).

between $25^{\circ}-45^{\circ} \mathrm{N}$ whereas Scotland is a considerable distance from the Iceland low (Fig. 4a). A similar inverse correlation can be seen between the salinity of ENACW at $(42,10)$ and that of mode water in the Rockall Trough west of Scotland (Ellet, 1993; Holliday et al., in press).

\section{CONCLUSIONS}

In summary it can be seen that the NAO reflects the wind regime and the precipitation pattern of the North Atlantic. These control the ocean-atmosphere fluxes, and the river discharge that results from pre- 
cipitation and evaporation over land. A succession of low NAO index winters in the late 1970s depressed the integrated NAO to a low in the 1980's (Fig. 3), corresponding to several years of high precipitation and river discharge west of Spain and France and hence low salinity at $42^{\circ} \mathrm{N}, 10^{\circ} \mathrm{W}$. Similarly, high values of the NAO elevated the integrated index in the early 1990's corresponding to low precipitation and high salinity. Thus the ocean acts as a rain gauge, and upper ocean salinity can be correlated with changes in the NAO.

Pollard and $\mathrm{Pu}$ (1985), examining falling salinity in the intergyre zone west of Spain in the late 1970s, asked "Where in the world did the oceans get saltier?" The answer is to be found on a smaller scale than they envisaged, namely that precipitation patterns shift with the NAO, so that the subpolar gyre salinifies and the intergyre zone freshens during low NAO periods, with the reverse occurring during high NAO periods such as the early 1990s.

\section{REFERENCES}

Bakun, A. - 1973. Coastal upwelling indices, west coast of North America, 1946-1971. NOAA Tech.Rep. NMFS SSRF-671, U.S: Dep.of Commerce, 103 pp.

Cayan, D.R. - 1992a. Latent and sensible heat flux anomalies over the northern oceans: driving the sea surface temperature. $J$. Phys. Oceanogr., 22: 859-881.

Cayan, D.R. - 1992b. Latent and Sensible Heat Flux Anomalies over the Northern Oceans: The Connection to Monthly Atmospheric Circulation. J. Climate, 5: 354-369

Cayan, D.R. and G. Reverdin. - 1994. Monthly precipitation and evaporation variability Estimated over the North Atlantic and North Pacific. In: A.-M. Wilburn (ed.), The Atlantic Climate Change Program, pp 28-32. NOAA Geophysical Fluid Dynamics Laboratory, Princenton, N.J.

Cook,E.R., R.D. D'Arrigo and K.R. Briffa, - 1998. A reconstruction of the North Atlantic Oscillation using tree ring chronologies from North America and Europe. Holocene, 9: 9-17.

Dickson, R.R., J. Meincke, A.A. Malmberg and A.J. Lee. - 1988. The Great salinity anomaly in the northern north atlantic 19681982. Progr. Oceanogr., 20: 103-151.

Dickson, R., J. Lazier,J. Meincke, P. Rhines and J. Swift. - 1996. Long-term coordinated changes in the convective activity of the North Atlantic. Progr. Oceanogr., 38: 241-295.

Ellett, D.J. - 1993. Transit times to the N.E.Atlantic of Labrador Sea Water signals. International Council for the Exploration of the Sea, Hydrography Committee, C.M.1993/C:25: 12 pp.

Ellett, D.J. and W.R. Turrell. - 1992. Increased salinity levels in the NE Atlantic. ICES C.M. 1992/C:21

Harvey, J. - 1982. $\theta-\mathrm{S}$ relationships and water masses in the eastern North Atlantic. Deep-Sea Res. I, 29: 1021-1033.

Heath, M.R., E.W. Henderson, G. Slesser and E.M.S. Woodward. -
1991. High salinity in the North Sea. Nature, 352: 116.

Holliday, N.P., R.T.Pollard, J.F. Read and H. Leach. - 2000. Water mass properties and fluxes in the Rockall Trough; 1975 to 1998. Deep-Sea Res. I, 47: 1303-1332.

Hurrell, J.W. - 1995. Decadal trends in the North Atlantic Oscillation: regional temperatures and precipitation. Science, 269: 676-679.

Iselin, C.O.D. - 1939. The influence of vertical and lateral turbulence on characteristics of the waters at mid-depths. Trans. American Geophys. Union: 414-417.

Jenkins, W.J. - 1982. On the climate of a subtropical ocean gyre: Decade timescale variations in water mass renewal in the Sargasso Sea. J. Mar. Res., 40: 265-290.

Jones, P.D., T. Johnsson and D. Wheeler. - 1997. Extension to the North Atlantic Oscillation using early instrumental pressure observations from Gibraltar andSouth-West Iceland. Int. J. Climatol, 17: 1433-1450.

Lavin, A., J.M. Díaz del Rio, J.M. Cabanas and G. Casas. - 1990. Afloramiento en el noroeste de la península Ibérica. Indices de afloramiento para el punto $43^{\circ} \mathrm{N} 11^{\circ} \mathrm{W}$. Periodo 1966-1989. Inf. Tec. Inst. Esp. Oceanogr., 91: 40 pp.

Lazier, J.R.N. - 1995. The salinity decrease in the Labrador Sea over the past thirty years. In: Natural climate variability on decadal-to-century time scales, pp 295-304. (ed. National Research Council Climate Research Committee) Washingotn DC: National Academy Press.

Maillard, C. - 1986. Atlas hydrologique de 1'Atlantique Nord-Est. Publications IFREMER. 133 plates.

Pérez, F.F., A.F. Ríos, B.A. King and R.T. Pollard. - 1995. Decadal changes of $\theta$-S relationship of the Eastern North Atlantic Central Water (ENAW). Deep-Sea Res., 42: 1849-1864.

Pollard, R.T. and S. Pu. - 1985. Structure and circulation of the upper Atlantic ocean Northeast of the Azores. Progr. Oceanogr. 14: 443-462.

Pollard, R.T., M.J. Griffiths, S.A. Cuningham, J.F. Read, F.F. Pérez and A.F. Ríos. - 1996. Vivaldi 1991 - A study of the formation, circulation and ventilation of Eastern North Atlantic Central Water. Progr. Oceanogr., 37: 167-192.

Read, J.F. and W.J. Gould. - 1992. Cooling and freshening of the subpolar North Atlantic Ocean since 1960s. Nature, 360: 55-57.

Ríos, A.F., F.F. Perez and F. Fraga. - 1992. Water masses in the upper and middle North Atlantic Ocean east of the Azores. Deep-Sea Res. I, 39: 645-658.

Rogers, J.C. and H.van Loon. - 1979. The Seesaw in winter Temperatures between Greenland and Northern Europe. Part II. Some Oceanic and Atmospheric Effects in Middle and High Latitudes. Monthly Weather Review 107: 509-519.

Rogers, J.C. - 1984. The Association between the North Atlantic Oscillation and the Southern Oscillation in the Northern Hemisphere. Monthly Weather Review, 11: 1999-2015.

Schmitt, R.W. - 1981. Form of the temperature-salinity relationship in the central water: Evidence for double-diffusive mixing. $J$. Phys. Oceanogr., 11: 1015-1026.

Schmitt, R.W., P.S. Bogden and C.L. Dorman. - 1989. Evaporation minus precipitation and density fluxes for the North atlantic. $J$. Phys. Oceanogr., 19: 1208-1221.

Sy, A. - 1988. Investigation of large scale circulation patterns in the central North Atlantic: The North Atlantic Current, the Azores Current and the Mediterranean water plume in the area of the Mid-Atlantic Ridge. Deep-Sea Res., 35: 383-413.

Sy, A., M. Rhein, J.R.N. Lazier, K.P. Koltermann, J. Meincke, A. Putzka and M.Bersch. - 1996. Surprisingly rapid spreading of newly formed intermediate waters across the North Atlantic Ocean. Nature: 386, 675-679.

Scient. ed.: P.E. La Violette 